Historic, Archive Document

Do not assume content reflects current scientific knowledge, policies, or practices. 



\section{PHILBRICK'S NURSERY}

HĂŔDY SHRUBS, PERENNIALS, EVERGREENS AND NATTVE PLANTS Turtle Lake, N. Dak.

\section{PRICE LIST}

In this circular we are offering some of the newer shrubs, trees, peremnials, etc., that we have found from personal experience to be hardy and easily grown here.

A few dollars spent in planting the home grounds will add far more to the value of your property than it costs. You are actually paid for making your home more attractive.' Few people see the inside of your home. You are judged by outside appearances.

\section{BE SURE TO LOOK OVER OUR SPECIAL COLLECTIONS}

On all orders of $\$ 5.00$ or over, received before March 20 th, we will give a discount of 5 per cent. Send cash with order.

All orders for $\$ 2.00$ or more will be shipped prepaid within zone 3 , except orders for Evergreens and Shade. Trees, which will be F. O. B. Turtle Lake, or Washburn, N. Dak.

Uur nursery has been state inspected and a Certificate of Examination will be attached to each shipment.

We will replace once, at half price, any nursery stock that fails to start to grow, if reported to us with proper proof by August 1, following date of purchase.

REFERENCE: First State Bank, Turtle Lake, N. Dak.

\section{FRUIT TREES}

Anoka Apple, $3-4$ ft. $\$ .55$ each, 3 for $\$ 1.50$. Crab Apples, Florence, high quality; Virginia, hardy red crab; Whitney, heavy yielder; prices of crabs, $3-4$ ft. $\$ .40$ each; 3 for $\$ 1.10$. PLUMS-Underwood and Redwing, 3$4 \mathrm{ft}$. trees, each $\$ .50,3$ for $\$ 1.30$.

Hansen Hybrids-Opata, heavy yielier; Sapa, good fresh or canned; Oka Cherry, outstanding variety of delicious flavor; Compass Cherry, dependable; $3-4 \mathrm{ft}$. each $\$ .45,3$ for $\$ 1.25$.

SANDCHERRIES - $18,-24$ in., each $\$ .15,3$ for $\$ .40$.

GOOSEBERRIES - H o u g h t o n, 3 plants $\$ .30$. Van Fleet, out yielded all other varieties at the Northern Great Plains Station, Mandan, N. Dak, \$:30 each, 3 for $\$ .75$.

CURRANTS-North Star; and Iondon Market; both are leading varieties at the Government Station near Mandan, 3 for $\$ .60,6$ for $\$ 1.00$.
RASPBERRIES-Latham, 6 for $\$ .25$, 12 for $\$ .40$.

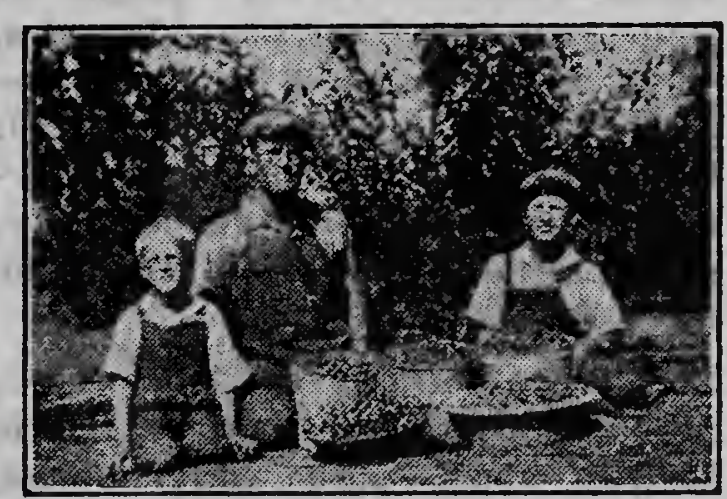

The Fruit from 3 Opata Trees in 1930.

SHADE \& SHELTER BEIT TREFS

Caragana, 12-18 in., each $\$ .10,10$ for $\$ .50,100$ for \$2.75; Green Ash, 4-6 ft., each $\$ .25,10$ for $\$ 1.75,300$ for $\$ 14.00$; Box Elder, $3-4$ ft., 10 for $\$ .75$, 100 for $\$ 6.00$; Northwest Poplar, 3-4 ft., each $\$ .25,5$ for $\$ 1.00$; Chinese Elm, $2-3 \mathrm{ft}$, 3 for $\$ .50,10$ for $\$ 1.50$; American Elm, 4-6 ft., each $\$ .30$, 5 for $\$ 1.35$, 10 for $\$ 2.50$. 


\section{EVERGREENS}

Evergreeris will have their roots puddled in mud and packed in wet moss. This is the cheapest way to ship them. We have found that Evergreens packed in this way can be shipped hundreds of miles with good success. If desired Balled and Burlapped, add 30c per tree extra.

Scotch Pine-10-12, in., each \$.35, 3 for $\$ .90 \%$ Mugho Pine-a hardy dwarf pine that forms a bushy, compact ball, never growing over $4 \mathrm{ft}$. high, in the spring looking like a multitude of tiny candles over the tree, 6 to 8 in., each $\$ .60 ; 8-12$ in., each $\$ .85$. Bad Lands Cedar-12-18 in., each $\$ 1.10$. Colorado Juniper-Red Cedar native of the Black Hills and of Colorado, 8-10 in., each \$.75. Black Hills Spruce-12-18 in., $\$ .80$ each. Colorado Blue Spruce10-15 in., $\$ 1.25$ each. Selected Colorado Blue Spruce Shiners-12-18 in., $\$ 2.50$ each.

\section{SHRUBS}

Lilacs-Common variety, purple or white, each $\$ .20,3$ for $\$ .50$; Japoniea, $18-24$, in , $\$ 50$ each, 3 for $\$ 1.40$; Josikea, $12-18$ in., $\$ .40$ each, 3 for $\$ 1.10$; Rothomagensis, reddish purple flowers; 3-4 ft., each \$.65; Persian Lilac, pale lilac flowers, $18-24$ in., each $\$ .40$, 3 for $\$ 1.10$.

FRENCH HYBRID LILACS-M.C. Perier, double creamy white; Marie LeGrey, single pure white; Congo, single. wine red; Belle DeNancy, double flowers, pinkish tint; Hybrid lilacs are :much superior to the common kinds. $12-18$ in., each $\$ .60,3$ for $\$ 1.65$.

ROSES-Hansa, crimson; Harrison's Yellow; Sarah VanFleet, rose pink; Belle Portevine, pink; Hugonis, single yellow; each \$.70. Double White Rose; Double Pink June Rose; White Spinecissema, double; Tetonkaha, single deep pink; $\$ .40$ each.

\section{SHRUBS-Continued}

SUMAC-Smooth Leaf; Fern Leaf; $\$ .25$ each. Aromatic Sumac; $\$ .40$.

HONEYSUCKLE-Morrowi; also $\mathrm{r} \in \mathrm{d}$, pink or white; $18-24$ in., each $\$ .25$.

ELDERS-Cut leaf; Golden Elder; 18-24 in.; each \$.35. Red Berry Elder, each $\$ .25$.

SPIREA-Billardi; Van Houtte; each \$.20. Arguta; Froebelli and Sorbifolia, (ash-leaved) 18-24 in., each $\$ .30$, 3 for $\$ 80$. Spirea Tricocarpia, white flowers, rare, 18-24 in., each $\$ .50$.

COTONEASTER-18-24 in., each $\$ .30$. YELLOW FLOWERING CURRANT -each \$.35. $\because$ SNOWBALL - Opulus Sterilis ; $\$ .40$ each. PHILADELPHUS -(Mock Orange) Coronarius a nd Grandiflora, white flowers, 18-24 in., each \$.40. HIGH BUSH CRANBERRY - handsome native, fruit used for jelly, each \$.45. SIBERIAN ALMOND - early pink flowers, handsome. also useful for bees, each $\$ .30,3 \cdot$ for $\$ .75,6$ for $\$ 1.25$. VINES-Clematis or Virgin's Bower, each \$.20. Engelmann's Ivy, each \$.30. Native Hop Vine, each $\$ .15$.

\section{PEONIES}

Prices on Peonies, Iris and Perennials, etc., are prepaid.

We list some of the newer and best varieties. "We offer some expensive varieties for less than half the price asked for them in 1931: The figures given before the name are the ratings given them by the American Peony Society. The letter following the name indicates the blooming season, thus: $\mathrm{E} \div$-early, $\mathrm{M}-$ midseason; : $\mathrm{L}-$ late. 3 to 5 eye roots. 9.3 Festiva Maxima, (E) white; each $\$ .40 ; 8.1$ Couronne D'or, (L) ivory white, each $\$ .35 ; 9.2$ E. B. Browning, (L) a new $\$ 5.00$ peony, a large. white, with outer petals heavily striped : crimson, .our price, each . $\$ 2,25 ; 9.2$ Mons.. Jules Elie (E-M) a large lilac pink, each 


\section{PEONIES-Continued}

$\$ .85 ; \quad 8.6$ Albert Crousse, (L) large, fresh salmon pink, $\$ .60 ; \cdots$ 8.7. Elwood Pleas, (L-M), large, very fragrant, light shell pink, $\$ .70 ; 9.0$ M. W. Shay lor, (M) an expensive peony, dwarf habit, cup shaped, pure pink with creamy center and golden heart, each $\$ 2.25 ; 9.1$ Lady A. Düf, (M) blush pink, lighter center, each $\$ .90 ; 9.8$ Therese, (M), highest rating pink peony, large soft pink, each $\$ 1.75$; 8.8 Karl Rosefield, (E-M) velvet crimson, each $\$ .75 ; 8.7$ Mary Brand, $(M)$ a good red, immensely productive, has no equal as a cut flower, each $\$ 1.00 ; 9.0$ : M. Martin Cahuzac, (M) large well formed balls of deep maroon, (purple garnet) the darkest peony grown, each $\$ 1.60$.

\section{IRIS}

There are many reasons for the increasing demand for the iris. "No garden should be without them. They are perfectly hardy, easily grown and come in a wide range of colors. We offer some of the best varieties at very reasonable prices. Iris. Ambas. sadeur, smoky purple-maroon, each $\$ 30$; Lord of June, violet blue, $\$ .30$; Queen Caterina, lavender violet, $\$ 25$; Blue Bird, clear blue, recommended, $\$ 20$; Dream, a fine pink, $\$ .35$; White Knight, snow white \$.20; Sherwin Wright, a golden yellow, $\$ .20$ Monsignor, velvety purple, each $\$ .15$; Nibelungen, fawn and purple, $\$ .15$ Rhein Nixe, white and vioket; $\$ .15$; Dwarf Iris, Sambo, rich purple, each $\$ .10,3$ for $\$ .25$.

\section{GLADIOLUS BULBS}

Carmen Sylva, pure white, 2 for $\$ .15$; 2 Gold, yellow, 2 for $\$ .15$; Cardinal Manning, fine red, 2 for $\$ .20 ; W$. H. Phipps, La France pink, 2 for $\$ .25$; COLLECTION-8 bulbs, 2 of each variety for $\$ .60$ postpaid.

\section{PERENNIALS}

Crimson Yarrow; Columbine, mixed; Cypress Spurge or Grave Yard Moss, a good ground cover; Delphinium, mixed; Gaillardia; Harebell, blue; Iceland Poppy, peach color; Lychnis, red; New England Asters, purple; Old Man; Old Woman; Painted Daisy; Platycodan, blue; Ribbon Grass; Shasta Daisy; Stonecrop; Sweet William; Tiger Lilies;: Orange Lily; Yucca Glacu;: The above perennials are $\$ .15$ each, 7 for $\$ 1.00$ postpaid.

The following are $\$ .20$ each, 6 for $\$ 1: 00$; Bocconia, " or PPlume Poppy, creamy white flowers; " $D$ i a nt hus (pinks). Deltoide; Dianthus Plumarius; Delphinium Belladona; Delph. Bellomosa; Spiderwort, blue; Pentstemon Grandiflora; Named Phlox, Miss Lingard, white; Champs Elysees, purplish red; Rhinelander, salmon pink with red eye; Milly VonHoboken, pink; Europa, white with crimson eye; and Phlox Diváricata; Columbine, long spurred variety.

Heartsease-a pansy violet, blooms all summer, 6 plants for $\$ .30$.

Lillies-Sib. Coral Lily, a splendid. hardy, medium sized lily with waxen flowers of deep scarlet color; Lilium Regale, has large beautiful white flowers with yellow centers, hardy. Prices on lily bulbs, each $\$ .25,3$ for $\$ .65$.

Oriental Poppy-Has very large brilliant red flowers, must be planted early in spring, hardy desirable, each \$.25.

Bleeding Heart-Spectabilis, each $\$ .45$. Dictamnus-Gas Plant, an interesting plant with dark ash-like foliage, white flowers, hardy, each $\$ .35$.

Dahlias-Purple Show; Sylvia,(Dec.) mauve pink; R obert Bıomfield. (Show) white; C. W. Bruton, (Dec.) yellow; Pride of Shelby, (Dec.) early, maroon red; Oregon Beauty, (Dec.) red; each $\$ .25$. One tuber of each variety for $\$ 1.00, P . P$. 


\section{SPECIAL COILECTIONS}

FRUITS-One Florence Crab; One Underwood; One Opata; One Oka; Two Van Fleet Gooseberry. Special price $\$ 2.00$

SHRUBS-One M. C. Periei French Lilac; Double White Rose; Fern Leaf Sumac; Siberian Almond; Spirea Sorbifolia. Special price

$\$ 1.50$.

EVERGREENS-One of each, Mugho Pine, 6-8 in.; Col. Júniper; Col. Blue Spruce; and Col. Blue Spruce Shiner. Special price $\$ 4.40$.

PEONIES - One of each, E. B. Browning, white; M. W. Shaylor, pink; M. Martin Cahuzac, deep maroon. Three good ones. Special price $\$ 5.50$. CÓLLECTION NO. 2-E. B. Browning, white; Lady A. Duff, blush pink; Mary Brand, red; Special price \$3.50. COLLECTION NO. 3-Couronne D'or, white; Elwood Pleas, shell pink; Karl Rosefield, red; Speçial price \$1.40.

IRIS-One of each. Ambassadeur; Blue Bird; Dream; White Knight: Sherwn Wright; Special price $\$ \mathbf{\$ 1 . 0 0}$

FRUIT COLLECTION NO. 4.-2f Fruit Trees and Bushes for $\$ 4.75$ Prepaid. 2 Sapa; 2 Opata; 2 Oka Cherry: 2 Compass Cherry; 6 Sandcherry; 3 North Star Currants and 3 Van Fleet Gonseberrys.

\section{SHELTER BELT COLLECTION}

50 Chinese Elm 6-12 in.; 50 Caragaṇa 12-18 in.; 25 American Elm 4 ft.; 50 Box Elder 2-3 ft.; 50 Green Ash 3-4 ft.; 50 Northwest Poplar 2-3 ft. Shipped; not prepaid, for $\$ 11.50$. Or one half of the collection for $\$ \$ 6.25$.

\section{SPECIAL SHRUB COLLECTION}

24 Plants prepaid for $\$ 7.00$. 2 Persian Lilac; 2 M. C. Periér French Lilacs; 2 Double Pink June Roses; 1 Harrison's Yellow Rose; 1 Double White Rose; 1 Cut Leaf Elder; 1 Smooth Leaf Sumac; 2 Fern Leaf 'Sumac; 2 Sib. Almonds; 2 Honeysuckle Pink; 2 Honeysuckle Red; 2 Spirea Arguta; 2 Spirea Sorbifolia; and 2 Clematis Vines.

\section{SPECIAL PERENNIAL COLLECTION}

36 Choice Perennials prepaid for $\$ 5$.25. 2 Blue Bird Iris; 2 Dream Iris, pink; 2 White Knight Iris; 2 Sherwin Wright Iris, yellow; 2 Monsignor, purple; 3 Spiderworts; 3 Pëntstemon; 3 Columbine, mixed; 2 Sib. Coral Lily; 1 Bleeding Heart; 6 Heartsease; 1 Oriental Poppy ; 2 Iceland Poppy ; 2 Tiger Lilies; 3 Naned Phlox;

IF YOU ARE IN NEED OF OTHER NURSERY STOCK, WRITE US. PLANT WHILE PRICES ARE LOW.

\section{PHILBRICK'S NURSERY}

Hardy Shrubs, Perennials, Evergreens and Native Plants Turtle Lake, N. Dak.

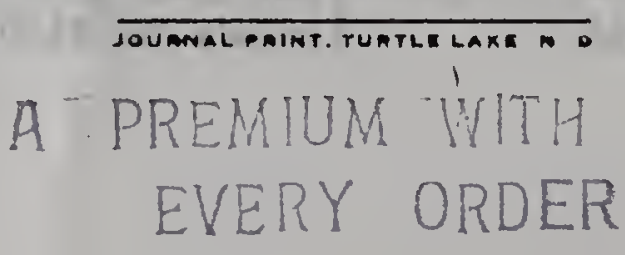

